\title{
Relationship of Body Temperature to the Lethal Action of Bacterial Endotoxin*
}

\author{
Roger P. Atwood † and Edward H. Kass \\ (From the Channing Laboratory, Mallory Institute of Pathology, Thorndike Memorial \\ Laboratory, Second and Fourth [Harvard] Medical Services, Boston City Hospital, \\ and the Departments of Bacteriology and Immunology, and Medicine, \\ Harvard Medical School, Boston, Mass.)
}

Although an extensive descriptive literature on fever and the influence of temperature upon biologic systems exists, there has been relatively little direct experimental evidence on whether fever is favorable or unfavorable to survival in infectious diseases (1). Opinions on this question range from the assumption that fever has evolved as a mammalian response to infection that generally has survival value for the host to the attitude (reminiscent of that held by physicians of earlier times) that fever is in itself deleterious and should be prevented. Except in certain instances in which elevated body temperature directly affects survival of the infectious agent, little data are available with which to approach this question (1).

In 1909 Ruata observed that injections of various gram-negative bacilli were more lethal for guinea pigs kept at elevated than at ordinary environmental temperatures (2). Two reports have appeared indicating a potentiating effect of high environmental temperatures upon the mortality of mice injected with endotoxin $(3,4)$, but in both of these the effect was incompletely described and was documented only as an incidental observation.

Recently, Connor and Kass (5) observed that artificial fever, induced by means of elevated ambient temperature, increased the susceptibility of mice to the lethal action of endotoxin. A similar effect (though slightly less pronounced) has also been observed in rats (6). It has long been

* Submitted for publication June 11, 1963; accepted October 3, 1963.

Aided by grant no. AI 02582 from the National Institutes of Health, U. S. Public Health Service. Presented in part at the Symposium on Bacterial Endotoxins, Institute of Microbiology, Rutgers, the State University, New Brunswick, N. J., September, 1963.

$\dagger$ Postdoctoral research fellow, U. S. Public Health Service. known that mice, rats, and guinea pigs exhibit hypothermia in response to endotoxin under usual laboratory conditions in contrast to the hyperthermia generally observed in man, rabbits, dogs, cats, and other species (7-16). In the experiments cited above $(5,6)$, when the mice and rats were challenged with endotoxin at ordinary room temperature, they exhibited the usual hypothermic response, whereas at elevated ambient temperatures the animals exhibited a further rise in body temperature upon challenge with endotoxin. The observed increase in susceptibility to the lethal action of endotoxin seen in the hyperthermic mice and rats might represent an artifact of the experimental situation resulting from the change from the usual hypothermic response to an artificially induced hyperthermic response foreign to these species.

The present studies were therefore undertaken to determine whether induced fever alters the lethality of endotoxin in a species that regularly exhibits fever in response to endotoxin. In our experiments, fever was produced in rabbits by elevated environmental temperatures or by pharmacological means. Animals with induced fever were challenged with endotoxin, and their susceptibility to the lethal action of endotoxin was compared with that of appropriate controls.

It will be shown $a$ ) that fever induced either by physical or pharmacological means increases the susceptibility of rabbits to the lethal action of endotoxin and $b$ ) that prevention of fever by simple physical means exerts a protective effect upon rabbits challenged with endotoxin.

\section{Methods}

Animals. A total of 120 female albino New Zealand rabbits, weighing 1.6 to $2.3 \mathrm{~kg}$, were used. In the animal colony they were caged singly and fed a standard 
commercial pellet diet. They had free access to water at all times. No animals were used whose base-line rectal temperatures fell outside the range 38.0 to $39.8^{\circ} \mathrm{C}$. Animals were used only once. Shorn rabbits were prepared by restraining the animals without anesthesia and shearing the fur with fine-toothed electric clippers close to the skin over the ears, face, head, neck, body, and limbs, but sparing the paws.

Endotoxin. The endotoxin used was derived from Salmonella typhosa (0901). ${ }^{1}$ Samples of the endotoxin were suspended in sterile, pyrogen-free, physiological saline at a concentration of $1,000 \mu \mathrm{g}$ per $\mathrm{ml}$. This opalescent suspension was subdivided into sterile rubber-capped vials that were frozen and maintained at $-20^{\circ} \mathrm{C}$. For each experiment a supply was thawed and used immediately. Any endotoxin remaining in the thawed vial was discarded. For lower dose ranges, dilutions with sterile, pyrogen-free saline were made from freshly thawed stock suspensions of endotoxin.

D-Lysergic acid diethylamide $(L S D) .^{2}$ LSD was supplied as a solution in sterile, pyrogen-free saline at a concentration of $100 \mu \mathrm{g}$ per $\mathrm{ml}$ and also contained 0.06 $\mu \mathrm{g}$ tartaric acid per $\mathrm{ml}$ added by the manufacturer to stabilize the LSD in solution.

Injections. Injections were made with sterile, pyrogen-free disposable tuberculin syringes at volumes between 0.2 and $1.0 \mathrm{ml}$. Larger doses of endotoxin were administered to shorn rabbits at the concentration of the stock suspension, thus requiring injections of 1 to $8 \mathrm{ml}$, which were given with larger disposable syringes. All injections of endotoxin and LSD were intravenous via the marginal ear vein.

Environmental temperature. A warm room, lined with aluminum foil and measuring $6 \times 7 \times 4$ feet was kept at $37^{\circ} \pm 0.5^{\circ} \mathrm{C}$ by a thermostatically controlled electric heater. This provided dry heat (relative humidity 30 to $40 \%$ ), the only moisture source being the animals' water bottles. The room was furnished with regular animal cages and a work table. Floor to ceiling temperature gradients were eliminated by a large electric fan.

Animals in the stock colony and laboratory were at $23^{\circ}$ $\pm 3^{\circ} \mathrm{C}$, hereinafter referred to as room temperature.

Body temperature recording. Rectal temperatures were measured electronically with thermistor probes and a Telethermometer. ${ }^{3}$ The majority of rabbits in each group were kept unrestrained in their cages throughout the experiments, but continuous recordings of rectal temperatures were obtained from some animals in each group with the Yellow Springs model 80 paper recorder. During continuous recordings the animals were restrained in the usual upright position, with free access to water bottles, by a loosely fitting wooden neck clamp fastened to a flat board. Preliminary recordings of

${ }^{1}$ Lot no. 452309 . Purchased from the Difco Co., Detroit, Mich.

2 Obtained from the Sandoz Pharmaceutical Co., Hanover, N. J., through the courtesy of Dr. Craig Burrell.

${ }^{3}$ Manufactured by the Yellow Springs Instrument Co., Yellow Springs, Ohio. temperature were made for 1 to 2 hours until a stable base line was reached before injections were given.

Tabulation of data and statistical methods. In general, the lethal effect of endotoxin was manifested within 24 hours, but in the shorn animals, it was necessary to extend the mortality tabulation to 48 and 72 hours because of the long duration of endotoxin effects in these animals, whether leading to death or to recovery. Estimates of the $\mathrm{LD}_{50}$ were made by the methods of Reed and Muench (17) and Berkson (18) and were in close agreement. The reported $L^{2}$ values were calculated by the method of Reed and Muench. Ranges of body temperature measurements indicated as \pm refer to the standard deviation of the mean.

\section{Results}

Comparative effects of endotoxin at $23^{\circ} \mathrm{C}$ and $37^{\circ} \mathrm{C}$. The lethality of the endotoxin was established in a group of 23 control rabbits given doses ranging from $50 \mu \mathrm{g}$ per $\mathrm{kg}$ to $450 \mu \mathrm{g}$ per $\mathrm{kg}$ and maintained at room temperature (Table I). Data in this control group were collected concurrently with those from the other experiments. The nature of the response to lethal or sublethal doses of endotoxin was not different from that described in the literature (19). No deaths occurred in less than 4 hours, the majority occurred between 4 and 8 hours, and all deaths in this group occurred within 16 hours after administration of endotoxin. With the large challenge doses of endotoxin used in these experiments, there was no consistent relationship between dose and febrile response (20) nor between the height of the maximal febrile response and the outcome, i.e., death or survival (Figure 1). Animals maintained at room temperature, and given endotoxin, generally survived beyond the early maximal temperature elevation, which ranged from $1.8^{\circ}$ to $3.1^{\circ} \mathrm{C}$, and deaths occurred during the defervescent phase. The estimated $\mathrm{LD}_{50}$ at room temperature was $240 \mu \mathrm{g}$ per $\mathrm{kg}$ (Table I), a figure in general agreement with those reported by other workers using various endotoxins (16).

When uninjected rabbits were maintained at $37^{\circ} \mathrm{C}$, their rectal temperatures began to rise within a few minutes and reached a mean level $2.1^{\circ} \pm 0.9^{\circ} \mathrm{C}$ above the initial temperatures within 2 hours. After 24 hours at $37^{\circ} \mathrm{C}$ the mean elevation of temperature was $1.8^{\circ} \pm 0.8^{\circ} \mathrm{C}$ (Figure 1). The animals exposed to the higher temperature exhibited moderate panting, increased. 
TABLE I

Influence of fever produced by elevated ambient temperature on the lethal action of endotoxin in rabbits

\begin{tabular}{|c|c|c|c|c|c|c|c|c|}
\hline & \multicolumn{2}{|c|}{$\begin{array}{c}\text { Ambient temp., } 23^{\circ} \mathrm{C} \\
\text { before and af ter } \\
\text { injection }\end{array}$} & \multicolumn{2}{|c|}{$\begin{array}{c}\text { Ambient temp., } 37^{\circ} \mathrm{C} \\
\text { before and after } \\
\text { injection }\end{array}$} & \multicolumn{2}{|c|}{$\begin{array}{l}\text { Ambient temp., } 23^{\circ} \mathrm{C} \\
\text { before and } 37^{\circ} \mathrm{C} \text { after } \\
\text { injection }\end{array}$} & \multicolumn{2}{|c|}{$\begin{array}{l}\text { Ambient temp., } 37^{\circ} \mathrm{C} \\
\text { before and } 23^{\circ} \mathrm{C} \text { after } \\
\text { injection }\end{array}$} \\
\hline & Endotoxin & Outcome & Endotoxin & Outcome & Endotoxin & Outcome & Endotoxin & Outcome \\
\hline & $\begin{array}{l}\mu g / \mathrm{kg} \\
50 \\
87 \\
130 \\
200 \\
200 \\
200 \\
200 \\
227 \\
250 \\
250 \\
250 \\
250 \\
250 \\
275 \\
275 \\
300 \\
300 \\
300 \\
400 \\
400 \\
400 \\
450 \\
450\end{array}$ & $\begin{array}{l}\text { Survived } \\
\text { Survived } \\
\text { Survived } \\
\text { Survived } \\
\text { Survived } \\
\text { Died } \\
\text { Died } \\
\text { Survived } \\
\text { Survived } \\
\text { Survived } \\
\text { Died } \\
\text { Died } \\
\text { Died } \\
\text { Died } \\
\text { Survived } \\
\text { Died } \\
\text { Died } \\
\text { Died } \\
\text { Survived } \\
\text { Died } \\
\text { Died } \\
\text { Died } \\
\text { Died }\end{array}$ & $\begin{array}{c}\mu g / \mathrm{kg} \\
1.0 \\
1.0 \\
2.0 \\
4.0 \\
5.0 \\
5.0 \\
10 \\
10 \\
10 \\
10 \\
10 \\
25\end{array}$ & $\begin{array}{l}\text { Survived } \\
\text { Survived } \\
\text { Survived } \\
\text { Died } \\
\text { Died } \\
\text { Died } \\
\text { Survived } \\
\text { Died } \\
\text { Died } \\
\text { Died } \\
\text { Died } \\
\text { Died }\end{array}$ & $\begin{array}{c}\mu g / \mathrm{kg} \\
1.0 \\
2.0 \\
2.0 \\
5.0 \\
5.0 \\
10 \\
10 \\
10 \\
10 \\
10 \\
20 \\
25\end{array}$ & $\begin{array}{l}\text { Survived } \\
\text { Survived } \\
\text { Died } \\
\text { Died } \\
\text { Survived } \\
\text { Survived } \\
\text { Survived } \\
\text { Survived } \\
\text { Survived } \\
\text { Died } \\
\text { Died } \\
\text { Died }\end{array}$ & $\begin{array}{l}\mu g / \mathbf{k g} \\
150 \\
150 \\
150 \\
150 \\
150 \\
150 \\
300 \\
300 \\
300 \\
300\end{array}$ & $\begin{array}{l}\text { Survived } \\
\text { Survived } \\
\text { Survived } \\
\text { Survived } \\
\text { Survived } \\
\text { Survived } \\
\text { Died } \\
\text { Survived } \\
\text { Survived } \\
\text { Died }\end{array}$ \\
\hline $\begin{array}{l}\text { Total no. of } \\
\text { rabbits: } \\
\text { LD }_{50, \mu g / k g}\end{array}$ & 23 & 240 & 12 & 4 & 12 & 13 & 10 & 300 \\
\hline
\end{tabular}

warmth and vasodilatation in the ears and skin, and recumbent (but alert) posture. Also, some used drinking water or saliva to wet the fur of the head and fore-paws by "face-washing" be-

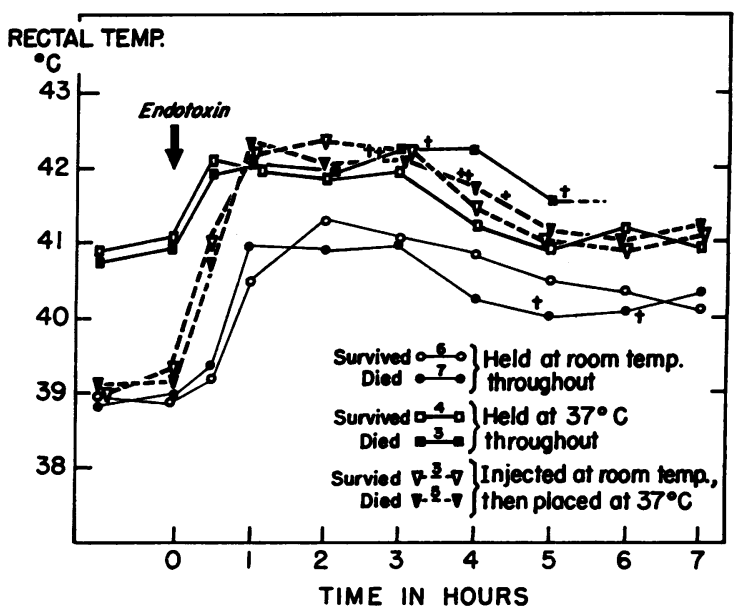

Fig. 1. INFLUENCE OF AMBIENT TEMPERAtURE UPON FEVER AND SURVIVAL AFTER ENDOTOXIN CHALLENGE IN RABBITS. Numbers appearing over symbols indicate number of animals represented by each point. Crosses indicate times of death of individual animals. havior, presumably in attempts to regulate body temperature. In addition to the 22 animals held at $37^{\circ} \mathrm{C}$ overnight in preparation for injection, 12 rabbits of the same age and size range as those used in this study were held at $37^{\circ} \mathrm{C}$ continuously for 4 days with no mortality.

Animals injected with endotoxin and maintained at $37^{\circ} \mathrm{C}$ were divided into two groups: those maintained and injected at room temperature and then placed immediately at $37^{\circ} \mathrm{C}$ and those held overnight at $37^{\circ} \mathrm{C}$ and then injected and continued at that temperature after injection (Table I). The rectal temperatures of rabbits injected with endotoxin and then placed at $37^{\circ} \mathrm{C}$ rose more rapidly and reached consistently higher levels than those of animals held at room temperature (Figure 1). The elevated rectal temperatures of animals that had been held overnight at $37^{\circ}$ before the administration of endotoxin rose still further after endotoxin and reached hyperthermic levels similar to those of animals placed at $37^{\circ} \mathrm{C}$ only after injection (Figure 1).

The $\mathrm{LD}_{50}$ of endotoxin was substantially smaller in animals exposed to $37^{\circ} \mathrm{C}$ before the injection 
of endotoxin than in those placed at $37^{\circ} \mathrm{C}$ only at the time of challenge with endotoxin; this agrees with observations in mice (5). Thus, the $\mathrm{LD}_{50}$ of endotoxin was reduced from $240 \mu \mathrm{g}$ per $\mathrm{kg}$ at room temperature to $13 \mu \mathrm{g}$ per $\mathrm{kg}$ in animals injected at room temperature and then placed at $37^{\circ} \mathrm{C}$, and to $4 \mu \mathrm{g}$ per $\mathrm{kg}$ in animals maintained at $37^{\circ} \mathrm{C}$ before and after injection (Table I).

In both groups of rabbits exposed to $37^{\circ} \mathrm{C}$, intense vascular congestion became grossly visible in the bulbar conjunctivae within 5 to 10 minutes after injection with endotoxin. A similar ocular vascular reaction to endotoxin was observed in animals kept at room temperature, but it did not develop until after fever had appeared and was generally less intense than in animals at $37^{\circ} \mathrm{C}$. This ocular hyperemia was not seen in uninjected animals at $37^{\circ} \mathrm{C}$ nor in those made febrile with LSD alone. Ophthalmoscopic inspection of the larger vessels of the ocular fundi revealed no distinctive vascular changes during fever and endotoxemia.

The lethal action of endotoxin was also accelerated at $37^{\circ} \mathrm{C}$, with death occurring in most animals within 4 hours after injection. Survival for 9 hours after injection of endotoxin at the higher temperature invariably indicated ultimate survival of the animal.

Temperature responses were similar in animals surviving or succumbing to endotoxin at the higher temperature, indicating that hyperpyrexia was not the sole factor determining the lethal outcome.

Effect of endotoxin during LSD-induced fever. LSD, an ergot alkaloid, was first shown to be pyrogenic for rabbits by Horita and Dille (21). The fever in rabbits is produced by doses in the microgram range, has virtually no lag phase, is dose related, and is predictable in its magnitude and duration $(21,22)$. Horita and Dille (21) also showed that during LSD-induced fever in rabbits the surface temperature of the ears falls to hypothermic levels and the body surface temperature remains unchanged as the deep body temperature rises to hyperthermic levels, indicating that cutaneous vasoconstriction and decreased heat loss are involved in LSD-induced pyrogenesis. Our observations confirm these findings and are of special interest in contrast to the aforementioned cutaneous vasodilatation observed in rabbits made febrile by exposure to $37^{\circ} \mathrm{C}$.

In the present studies, LSD, at a dose of $50 \mu \mathrm{g}$ per $\mathrm{kg}$ at room temperature, produced fevers in rabbits comparable to those others have observed $(21,22)$. In all experiments a standard interval of 45 minutes elapsed between the administration of LSD and the subsequent challenge with endotoxin to allow time for LSD-induced fever to be at or near its maximal level. In 17 rabbits the mean rectal temperature 45 minutes after injection of $\mathrm{LSD}$ was $40.6^{\circ} \pm 0.15^{\circ} \mathrm{C}$, an elevation of temperature close to that obtained by placing the animals at $37^{\circ} \mathrm{C}$.

As shown in Figure 2, the administration of endotoxin to rabbits pretreated with LSD resulted in further rises in rectal temperatures to levels similar to those observed in animals challenged with endotoxin at $37^{\circ} \mathrm{C}$. In Figure 2, as in Figure 1 , the temperature curves for those animals that survived and those that died have been plotted separately and show no significant differences, suggesting that the lethal outcome was not determined by the degree of hyperpyrexia alone.

Rabbits pretreated with LSD were indistinguishable from those maintained at $37^{\circ} \mathrm{C}$ in their rapid development of tachypnea, dyspnea, diarrhea, and ocular hyperemia in response to endotoxin. Pretreatment with LSD accelerated the lethal outcome following challenge with endotoxin, and the $\mathrm{LD}_{50}$ of the LSD-treated group was $7 \mu \mathrm{g}$ per

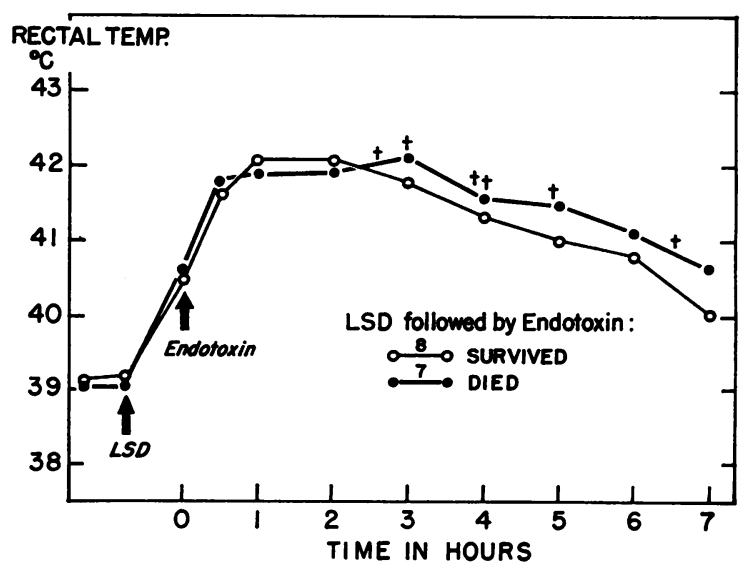

Fig. 2. Influence of Pharmacologically (LSD) INDUCED FEVER UPON FEVER AND SURVIVAL AFTER ENDOtoxin Challenge. Symbols as given for Figure 1. Ambient temperature, $23^{\circ} \mathrm{C}$. LSD, D-lysergic acid diethylamide. 
$\mathrm{kg}$ (Table II), a value comparable to that observed in animals made hyperthermic by the warmer environment.

Effect of LSD and endotoxin on shorn rabbits. The possibility was considered that pharmacological actions of LSD other than the pyretogenic property might influence the susceptibility of rabbits to endotoxin by means unrelated to fever. To explore this possibility a way was sought to prevent the development of fever in rabbits given LSD; rabbits shorn of their fur satisfied this requirement in that they did not develop fever when given LSD in the standard dose used. Shorn animals at room temperature have rectal temperatures about $1^{\circ} \mathrm{C}$ lower than those with fur, as noted by Grant (23) and Fekety (24). The administration of LSD in the standard dose to shorn animals was associated either with no change in rectal temperature or in a rise of rectal temperature of less than $1^{\circ} \mathrm{C}$, resulting in temperatures no higher than the range for unshorn, uninjected rabbits at room temperature.

When shorn animals at room temperature were given $\mathrm{LSD}, 50 \mu \mathrm{g}$ per $\mathrm{kg}$, and challenged with endotoxin 45 minutes later, hypothermia occurred in all animals 30 to 45 minutes after injection of

TABLE II

Influence of pharmacologically (LSD) induced fever on the lethal action of endotoxin in rabbits*

\begin{tabular}{cl}
\hline Endotoxin & Outcome \\
\hline$\mu g / k g$ & \\
1.0 & Survived \\
1.0 & Survived \\
2.0 & Survived \\
2.0 & Survived \\
4.0 & Survived \\
4.0 & Survived \\
5.0 & Survived \\
5.0 & Survived \\
5.0 & Died \\
5.0 & Died \\
10 & Survived \\
10 & Died \\
10 & Died \\
10 & Died \\
15 & Survived \\
15 & Died \\
25 & Died \\
30 & Died \\
30 & Survived \\
50 & Died \\
50 & Died \\
Total no. rabbits: 21 & LD $1, \mu g / k g: 7$ \\
\hline & \\
\hline
\end{tabular}

*Ambient temperature, $23^{\circ}$ C. LSD, D-lysergic acid diethylamide.

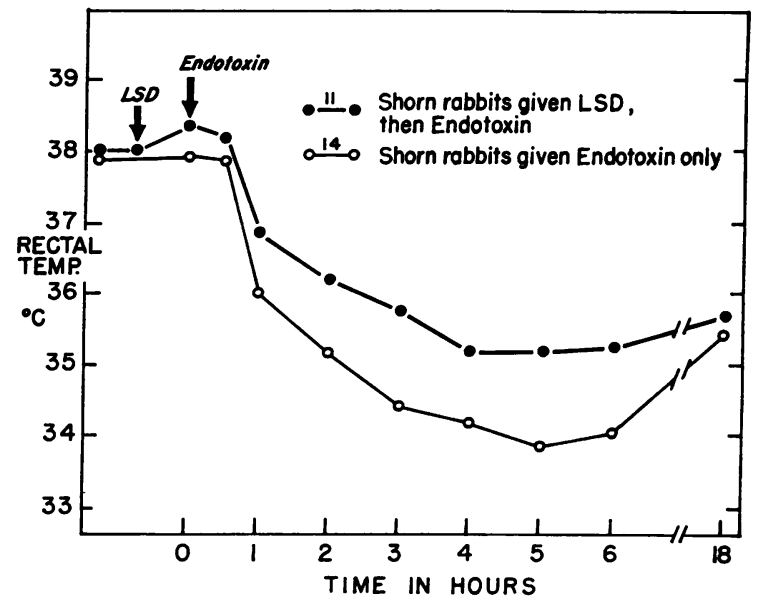

Fig. 3. INFLUENCE OF SHEARING (LOSS OF FUR) UPON BODY TEMPERATURE RESPONSE TO INJECTION OF LSD FOLLOWED BY ENDOTOXIN AND TO ENDOTOXIN ALONE. Ambient temperature, $23^{\circ} \mathrm{C}$. LSD, D-lysergic acid diethylamide.

endotoxin (Figure 3). Rectal temperatures fell $2.6^{\circ}$ to $6.5^{\circ} \mathrm{C}$ below pretreatment levels, and the hypothermia persisted for 18 to 72 hours after a single injection of endotoxin. No consistent relationship between the dose of endotoxin and the degree of hypothermia was observed, nor was there any relationship between the degree of hypothermia and the outcome, i.e., death or survival, probably because all doses of endotoxin were relatively large and produced maximal physiological disturbances that differed more because of individual animal variation than as a function of dose. Using smaller doses of endotoxin, Grant has shown a relationship between dose of endotoxin and degree of hypothermia in shorn animals exposed to cold (23).

The hypothermic response was characterized by crouching, immobility, coolness and cyanosis of the skin, diarrhea, failure to eat or drink, and marked delay in either the lethal outcome or recovery. No deaths occurred before 7 hours after injection of endotoxin, the majority of deaths occurred between 12 and 36, and several between 36 and 48 hours. Surviving animals exhibited hypothermia and the characteristic huddled appearance for as long as 72 hours.

Comparison of the $\mathrm{LD}_{50}$ values for endotoxin in Tables II and III shows that the $L_{50}$ was 60 times greater in shorn animals given LSD than in comparable LSD-pretreated, intact animals that developed fever in response to LSD. 
TABLE III

Influence of prevention of fever by shearing on the lethal action of endotoxin in rabbits*

\begin{tabular}{|c|c|c|c|c|}
\hline & \multicolumn{2}{|c|}{$\begin{array}{l}\text { Shorn rabbits given } \\
\text { LSD† and endotoxin }\end{array}$} & \multicolumn{2}{|c|}{$\begin{array}{l}\text { Shorn rabbits given } \\
\text { endotoxin alone }\end{array}$} \\
\hline & $\begin{array}{l}\text { Endo- } \\
\text { toxin }\end{array}$ & Outcome & $\begin{array}{l}\text { Endo- } \\
\text { toxin }\end{array}$ & Outcome \\
\hline & $\mu g / k g$ & & $\mu g / k g$ & \\
\hline & 100 & Survived & 150 & Survived \\
\hline & 100 & Survived & 400 & Survived \\
\hline & 150 & Survived & 400 & Died \\
\hline & 200 & Survived & 700 & Survived \\
\hline & 200 & Died & 1,000 & Survived \\
\hline & 250 & Survived & 1,500 & Died \\
\hline & 250 & Died & 2,000 & Survived \\
\hline & 300 & Survived & 2,000 & Survived \\
\hline & 300 & Survived & 2,500 & Survived \\
\hline & 300 & Survived & 2,500 & Died \\
\hline & 600 & Survived & 3,000 & Died \\
\hline & 1,000 & Died & 3,000 & Survived \\
\hline & 1,000 & Died & 3,500 & Survived \\
\hline & 1,500 & Died & 3,500 & Died \\
\hline & 1,500 & Died & 3,500 & Died \\
\hline & 2,000 & Died & 4,000 & Died \\
\hline \multirow{3}{*}{$\begin{array}{l}\text { Total no. of } \\
\text { rabbits: } \\
\text { LD }_{50}, \mu g / k g \text { : }\end{array}$} & & & & Died \\
\hline & 16 & & 17 & \\
\hline & & 420 & & 2,500 \\
\hline
\end{tabular}

* Ambient temperature, $23^{\circ} \mathrm{C}$.

$\dagger \mathrm{D}$-Lysergic acid diethylamide, uniform in dose of 50 $\mu \mathrm{g}$ per $\mathrm{kg}$ (see text).

Shorn rabbits were given graded doses of endotoxin at room temperature. As expected, they responded with hypothermia and with the same delayed death or recovery, and the same general appearance, as did shorn animals that had been pretreated with LSD before endotoxin challenge. The hypothermia was somewhat deeper in shorn animals receiving endotoxin alone as compared with those pretreated with LSD (Figure 3), but there was considerable overlap in the ranges of hypothermia observed in the two groups.

As shown in Table III, the shorn animals survived remarkably large doses of endotoxin and had an estimated $\mathrm{LD}_{30}$ of $2,500 \mu \mathrm{g}$ per $\mathrm{kg}$. This figure, some six times higher than the $L D_{50}$ for shorn rabbits pretreated with LSD, suggests that LSD may have exerted some adverse effect upon survival even in the absence of fever.

A further demonstration of the effect of fever upon the response to endotoxin was obtained by placing shorn animals at $37^{\circ} \mathrm{C}$ overnight and then challenging them with endotoxin. The increase in rectal temperature in 10 shorn rabbits at $37^{\circ} \mathrm{C}$ was $1.5 \pm 0.6^{\circ} \mathrm{C}$, a figure not far below that observed for furred rabbits at the same en- vironmental temperature. Shorn animals challenged with endotoxin at $37^{\circ} \mathrm{C}$ showed fever curves similar to those of furred animals, and the estimated $\mathrm{LD}_{50}$ in this group was $16 \mu \mathrm{g}$ per $\mathrm{kg}$ (Table IV). This figure is more than 150 times lower than that for shorn animals at room temperature, but somewhat higher than that obtained for furred rabbits at the higher temperature. Presumably the latter difference reflects the slightly greater increase in body temperatures that occurred in furred animals kept at $37^{\circ} \mathrm{C}$.

Finally, to rule out fixed injury resulting from exposure to $37^{\circ} \mathrm{C}$ that might influence the response to endotoxin, 10 rabbits were held at $37^{\circ} \mathrm{C}$ overnight, then injected with endotoxin and placed at room temperature immediately after injection. The body temperatures of all of these animals began to fall immediately after they were removed to the cooler environment, but their temperatures rose again in response to the challenge with endotoxin to levels comparable to those in control animals kept at room temperature throughout. The estimated $\mathrm{LD}_{50}$ was $300 \mu \mathrm{g}$ per $\mathrm{kg}$ (Table I), a figure close to that obtained for control animals maintained at room temperature before and after endotoxin challenge. Eight animals in this group survived endotoxin doses that should have been lethal had the animals continued to react to endotoxin as they did at $37^{\circ} \mathrm{C}$.

Autopsies were performed on animals dying of endotoxin effects in every experimental group. Specimens for histologic examination were taken from kidney, liver, spleen, lung, myocardium, thymus, stomach, ileum, colon, and brain and were

TABLE IV

Influence of fever produced by elevated ambient temperature on the lethal action of endotoxin in shorn rabbits*

\begin{tabular}{cl}
\hline Endotoxin & Outcome \\
\hline$\mu g / k g$ & Survived \\
1.0 & Survived \\
5.0 & Died \\
10 & Survived \\
10 & Died \\
25 & Survived \\
50 & Died \\
200 & Died \\
300 & Died \\
Total no. of rabbits: 9 & LD $_{50, \mu g} / \mathrm{kg}: 16$ \\
\hline
\end{tabular}

$* 37^{\circ} \mathrm{C}$ 
fixed in formalin and stained with hematoxylin and eosin. Characteristic findings were common to all groups. Scattered punctate hemorrhages were found in the thymus, myocardium, and colon, and intense congestion was grossly and microscopically present in lung, liver, spleen, and kidney of all animals examined. In all animals, we found margination of polymorphonuclear leukocytes in the pulmonary vasculature and varying accumulation of these cells in the alveoli and bronchioles, generally more extensive in animals surviving for longer periods before death. Otherwise, however, the morphologic findings in animals dying of endotoxin effects were uniform for all of the experimental groups.

\section{Discussion}

The data presented here demonstrate that induction of fever increases the susceptibility of rabbits to the lethal action of endotoxin, and conversely, that prevention of fever exerts a protective effect against such a lethal challenge. The effects of endotoxin were more rapid and more severe in hyperthermic animals regardless of whether hyperthermia was produced by pharmacological or physical means. Potentiation of the lethal action of endotoxin by artificial elevation of body temperature occurs in mice and rats $(5,6)$, two species that exhibit hypothermia in response to endotoxin under usual laboratory conditions. The present data show that this effect is also demonstrable in rabbits, a species that normally exhibits fever in response to endotoxin.

An effect of induced fever that may be pertinent has been observed by Bannister (25). Volunteers, who at normal body temperatures exhibited a certain febrile response to the administration of pyrogenic doses of endotoxin, were observed to have proportionately greater febrile responses to the same challenge when their resting body temperatures had been elevated by physical means. In the latter instances, as in the present experiments, fever produced by endotoxin seemed to be additive to that produced by physical means. Bannister noted that at elevated environmental temperature minute doses of endotoxin produced in man dangerously high fever and discomfort of such severity (including transient hypotension) as to make further experimentation unwise. $\mathrm{He}$ demonstrated that subjects in a heating cabinet with elevated body temperatures and profuse sweating developed anhidrosis after administration of endotoxin and that injection of pilocarpine into the skin of the anhidrotic subjects led to local restoration of sweating in the injected area. This demonstration that the peripheral sweating mechanism was intact led Bannister to conclude that inhibition of the sudomotor response resulted from the central action of endotoxin on the autonomic nervous system. The concept of a critical locus of action of endotoxin in the autonomic nervous system has received earlier support from the work of Reilly and his colleagues (26-28), Penner and Klein (29), Zahl and Hutner (11), Bennett, Petersdorf, and Keene (30), and others. Recent observations of Porter and Kass (6) also support the concept that the increased lethality of endotoxin in the febrile animals is mediated through a central mechanism. They observed that endotoxin was lethal in smaller doses when injected directly into the carotid arteries of rats than when administered via the aorta and that in rats made hyperthermic by elevation of the ambient temperature, the $\mathrm{LD}_{50}$ of endotoxin given via the carotid route decreased in proportion to the decrease in $L D_{50}$ by the systemic route. Stereotactic experiments have also shown that ablation of a posterior hypothalamic area protects against an otherwise lethal dose of endotoxin (31).

Mediation of the lethal action of endotoxin by effects on central thermoregulatory and vasomotor centers is also suggested by the present observations that $a$ ) elevated environmental temperature and LSD increase susceptibility to endotoxin despite the opposite peripheral vasomotor responses (vasodilatation and vasoconstriction, respectively) that accompany their use to produce fever, $b$ ) that peripheral vasomotor and thermal responses to endotoxin may be modulated by the resting body temperature during the early phases of the response to endotoxin $(5,6)$, and $c)$ that LSD, an autonomic stimulatory agent $(32,33)$, appears to increase significantly susceptibility to endotoxin even in animals that are prevented from becoming febrile by shearing their fur. ${ }^{4}$

\footnotetext{
4 Gilbert's (34) experiments on the influence of pretreatment with LSD upon the acute circulatory changes in cats after endotoxin challenge showed no adverse effect of LSD, but the experimental circumstances were so different as to constitute no contradiction of the pres-
} 
Fever and endotoxin may interact at central thermoregulatory and vasomotor control centers to produce the observed effects. Endotoxin, in affecting such centers, would be especially damaging to centers that, as in the present experiments, are already undergoing increased metabolic activity resulting from the preparatory induced fever.

There is evidence that induced fever in man potentiates the effects of small doses of endotoxin. This is shown by the aforementioned observations of Bannister (25) and also by studies, currently in progress, described by Wolff, Rubenstein, and Mulholland (35). Fever was induced in volunteers by a series of injections of the pyrogenic adrenal steroid etiocholanolone. Before and after the etiocholanolone, the subjects were challenged with small doses of endotoxin. The responses following etiocholanolone were exaggerated as compared to the response before the steroid-induced fevers. It seems likely, therefore, that the effect of fever in increasing susceptibility to the lethal action of endotoxin may be applicable also to man. If this is true, it may carry important therapeutic implications for the clinical management of systemic endotoxin producing infections, particularly in the earlier stages when high fever is commonly present before shock and spontaneous hypothermia supervene. Two reports have appeared in which moderate induced hypothermia has been used in the treatment of septic shock $(36,37)$. In both of these, the authors reported that hypothermia was of some benefit, but the case series were too small to draw valid quantitative conclusions concerning differences in case salvage rate with hypothermia.

Whether prevention of fever in endotoxemia is protective for man can only be settled by accumulation of a large and carefully matched case series because of the tendency for the outcome to be determined inevitably (irrespective of therapeutic measures) by the underlying disorder that gave rise to endotoxemia and by other features of the complex host response to infection.

ent findings. The "initial, acute" circulatory responses to endotoxin challenge studied and illustrated by Gilbert were those occurring within a few seconds after intravenous administration of endotoxin to anesthetized cats with cannulae placed in their carotid and pulmonary arteries.

\section{Summary}

1) The induction of fever in rabbits by physical means (elevation of environmental temperature) or by pharmacological means (administration of D-lysergic acid diethylamide, LSD) reduces the $\mathrm{LD}_{50}$ of bacterial endotoxin from approximately $240 \mu \mathrm{g}$ per $\mathrm{kg}$ to 4 to $13 \mu \mathrm{g}$ per $\mathrm{kg}$

2) Hyperthermic rabbits exhibit augmented febrile responses to endotoxin and acceleration of endotoxic effects leading to an earlier lethal outcome.

3) When rabbits are shorn of their fur, they invariably respond to endotoxic challenge at room temperature with profound hypothermia and are resistant to the lethal action of endotoxin with an $\mathrm{LD}_{50}$ approximately 10 times higher than that of unshorn animals challenged at room temperature.

4) When the body temperatures of shorn animals are elevated by exposure to elevated environmental temperature, the febrile response and $\mathrm{LD}_{50}$ of endotoxin are restored to levels characteristic of unshorn animals.

5) LSD augments the lethal action of endotoxin even in shorn, hypothermic rabbits.

6) The findings are explained on the hypothesis that increased metabolic activity of central vasomotor and thermoregulatory loci accompanies pyrogenesis and that such loci are increasingly susceptible to endotoxin as their metabolic activity increases.

\section{Acknowledgment}

The authors gratefully acknowledge the technical assistance of Miss Mei Lie Uong.

\section{References}

1. Bennett, I. L., Jr., and A. Nicastri. Fever as a mechanism of resistance. Bact. Rev. 1960, 24, 16.

2. Ruata, G. Q. L'influenza del caldo umido sulle infezioni. Bull. Sci. med 1909, 80, 59.

3. Andervont, H. B. The reaction of mice and of various mouse tumors to the injection of bacterial products. Amer. J. Cancer 1936, 27, 77.

4. Chedid, L., and F. Boyer. Etude comparative du pouvior antitoxique de la cortisone et de la chlorpromazine. Ann. Inst. Pasteur 1955, 88, 336.

5. Connor, D. G., and E. H. Kass. Effect of artificial fever in increasing susceptibility to bacterial endotoxin. Nature (Lond.) 1961, 190, 453.

6. Porter, P. J., and E. H. Kass. Mediation by the central nervous system of the lethal action of bacterial endotoxin. Clin. Res. 1962, 10, 185. 
7. Pfeifer, R. Untersuchungen uber das Choleragift. Z. ges. Hyg. 1891, 11, 393.

8. Sanarelli, J. Moyens de défense de l'organisme contre les microbes après vaccination et dans la guérison. Ann. Inst. Pasteur 1893, 7, 225.

9. Olitzky, L., and S. Avinery. The hypothermic factor of $B$. dysenteriae shiga. Brit. J. exp. Path. 1937, 18, 316.

10. Olitzky, L., S. Avinery, and P. K. Koch. The hypothermic and adreno-hemorrhagic effects of bacterial vaccines. J. Immunol. 1942, 45, 237.

11. Zahl, P. A., and S. H. Hutner. Temperature factors in the action of certain bacterial endotoxins. Proc. Soc. exp. Biol. (N. Y.) 1944, 56, 156.

12. Tal, C., and L. Olitzky. The toxic and antigenic properties of fractions prepared from the complete antigen of Shigella dysenteriae. J. Immunol. $1948,58,337$.

13. Anderson, W. H., and R. Broderson. Hypothermia in the mouse as a bio assay of endotoxin protection factor in impure penicillin. Proc. Soc. exp. Biol. (N. Y.) 1949, 70, 322.

14. Bennett, I. L., Jr., and P. B. Beeson. The properties and biologic effects of bacterial pyrogens. Medicine (Baltimore) 1950, 29, 365.

15. Berry, L. J., D. S. Smythe, and L. G. Young. Effects of bacterial endotoxin on metabolism. I. Carbohydrate depletion and the protective role of cortisone. J. exp. Med. 1959, 110, 389.

16. Zweifach, B. W. Aspects of comparative physiology of laboratory animals relative to the problem of experimental shock. Fed. Proc. 1961, 20, part III, suppl. 9, 18.

17. Reed, L. J., and H. Muench. A simple method of estimating fifty per cent endpoints. Amer. J. Hyg. 1938, 27, 493.

18. Berkson, J. Estimate of the integrated normal curve by minimum normit chi-square with particular reference to bio-assay. J. Amer. Statistical Ass. 1955, 50, 529.

19. Thomas, L. The physiologic disturbances produced by endotoxins. Ann. Rev. Physiol. 1954, 16, 467.

20. Keene, W. R., H. R. Silberman, and M. Landy. Observations on the pyrogenic response and its application to the bioassay of endotoxin. J. clin. Invest. 1961, 40, 295.

21. Horita, A., and J. M. Dille. Pyretogenic effect of lysergic acid diethylamide. Science 1954, 120, 1100.

22. Gogerty, J. H., and J. M. Dille. Tolerance to the pyretogenic effects of lysergic acid diethylamide. J. Pharmacol. exp. Ther. 1956, 116, 450.

23. Grant, R. Nature of pyrogen fever: effect of environmental temperature on response to typhoid- paratyphoid vaccine. Amer. J. Physiol. 1949, 159, 511.

24. Fekety, F. R. The effect of loss of fur upon fever in rabbits. Clin. Res. 1962, 10, 214.

25. Bannister, R. G. Anhidrosis following intravenous bacterial pyrogen. Lancet 1960, 2, 118.

26. Reilly, J., E. Rivalier, A. Compagnon, R. Laplane, and $H$. du Buit. Sur la pathogénie de la dothiénentérie. La fièvre typhoide expérimentale. Ann. Méd. 1935, 37, 182.

27. Reilly, J., E. Rivalier, A. Compagnon, R. Laplane, and $H$. du Buit. Sur la pathogénie de la dothiénenterie. Le rôle du systeme neurovégétatif dans la genèse des lésions intestinales. Ann. Méd. 1935, $37,321$.

28. Gastinel, P., and J. Reilly. Sur l'action pathogène des antigenes glucido-lipidiques du bacille d'Eberth. C. R. Soc. Biol. (Paris) 1940, 134, 456.

29. Penner, A., and S. H. Klein. The pathogenesis of experimental dysentery intoxication. Production of the lesions by cerebral circulation of the toxin. J. exp. Med. 1952, 96, 59.

30. Bennett, I. L., Jr., R. G. Petersdorf, and W. R. Keene. Pathogenesis of fever: evidence for direct cerebral action of bacterial endotoxins. Trans. Ass. Amer. Phycns 1957, 70, 64.

31. Kass, E. H., R. P. Atwood, and P. J. Porter. Observations on the locus of lethal action of bacterial endotoxin in Proceedings of the Symposium on Bacterial Endotoxins, Institute of Microbiology, Rutgers, the State University, New Brunswick, N. J., September 1963.

32. Rothlin, E. Lysergic acid diethylamide and related substances. Ann. N. Y. Acad. Sci. 1957, 66, 668.

33. Neubold, K., M. Taeschler, and A. Cerletti. Beitrag zur zentralen Wirkung von LSD: Versuche über die Lokalisation von LSD-Effekten. Helv. physiol. pharmacol. Acta 1957, 15, 1.

34. Gilbert, R. P. Effect of antihistaminic and antiserotonin drugs on vascular responses to $E$. coli endotoxin in the cat. Proc. Soc. exp. Biol. (N. Y.) 1959, 100, 346.

35. Wolff, S. M., M. Rubenstein, and J. H. Mulholland. Personal communication.

36. Blair, E., R. W. Buxton, R. A. Cowley, and A. R. Mansberger. The use of hypothermia in septic shock. J. Amer. med. Ass. 1961, 178, 916.

37. Cockett, A. T. K., and W. E. Goodwin. Hypothermia as a therapeutic adjunct in management of bacteremic shock after urological surgery. J. Urol. (Baltimore) 1961, 85, 358. 